\title{
Localism, governmentality and failing technologies: the case of neighbourhood planning in England
}

Article

Accepted Version

Wargent, M. (2021) Localism, governmentality and failing technologies: the case of neighbourhood planning in England. Territory, Politics, Governance, 9 (4). pp. 571-591. ISSN 2162268X doi: https://doi.org/10.1080/21622671.2020.1737209 Available at https://centaur.reading.ac.uk/89001/

It is advisable to refer to the publisher's version if you intend to cite from the work. See Guidance on citing.

To link to this article DOI: http://dx.doi.org/10.1080/21622671.2020.1737209

Publisher: Routledge

All outputs in CentAUR are protected by Intellectual Property Rights law, including copyright law. Copyright and IPR is retained by the creators or other copyright holders. Terms and conditions for use of this material are defined in the End User Agreement.

$\underline{\text { www.reading.ac.uk/centaur }}$ 
Central Archive at the University of Reading

Reading's research outputs online 


\title{
Localism, governmentality and failing technologies: the case of neighbourhood planning in England
}

\author{
Territory, Politics, Governance
}

\begin{abstract}
This paper seeks to analyse the localism agenda pursued in the UK since 2010 through the lens of governmentality. This examines how the state has deployed spatially-based technologies of government predicated on particular political rationalities of localism that seek to orchestrate the 'conduct of conduct'. The paper attempts to combat two oversights within the governmentality literature: first, the tendency to focus on the abstract, neglecting the messiness of actual attempts to govern; and second, the paucity of empirical studies of technologies that fall short of realigning subjects 'agency towards governmental goals - despite a long-standing recognition of the incomplete and often contradictory nature of governmental rationalities. Through an empirical exploration of local actors' experiences of Neighbourhood Planning - a community-led, land-use planning initiative - this paper seeks to address these shortcomings by demonstrating how fundamental misconceptions contained within contemporary political rationalities have undermined efforts to realign community agency toward housing delivery. In concluding, it is argued that the tensions and fault-lines found within these rationalities go some way to explaining the emergence of 'interstitial spaces of hope' for genuine community agency within the confines of gradually tightening governmentalities.
\end{abstract}

Keywords: neighbourhood planning; localism; governmentality; rationalities; technologies; governance.

\section{Introduction}

Localism is now a well established policy discourse in most Western liberal democracies, not least in the United Kingdom where it has become a mainstay of public policy for over two decades.

Proponents draw discursive links between localism and citizen empowerment, community control, responsive governance, and deepened democracy. More recent strands of localist discourse also speak to a classically liberal rejection of interventionist, 'big' government, seeking to juxtapose a distant, elite-dominated centre with knowable and responsive localities populated by communities of responsible citizens (Glasman, 2010; Norman, 2010). Specific articulations of localism therefore call upon a disparate set of political rationalities, allowing overlapping and frequently 
contradictory interpretations of 'the local' to be mobilised across the political spectrum (for a discussion of the contested uses and meanings of localism see Clarke and Cochrane, 2013: 10-11).

One unifying assumption made by successive UK administrations has been that power can simply be 'put in the hands' of local people (Blair, 1997; Cameron, 2011). This idea has long been problematised within the academic literature, not least by theorists adopting a governmentality perspective predicated on Foucault's (1990: 93) synaptic conception of power that "comes from everywhere", operating through social actors and their relations (Raco and Imrie, 2000; Raco, 2003; Swyngedouw, 2005; Taylor, 2007; Haughton et al., 2013; Davoudi and Madanipour, 2013). From this perspective, attempts to devolve power towards the local are never straightforward, nor necessarily empowering, but rather a reconfiguration of authority with actors exposed to new discursive practices that seek to constitute governable subjects and institute governmental technologies (Cruikshank, 1999; Dean, 2010).

This paper contributes to this literature through an analysis of the localism agenda adopted in England since $2010^{1}$ through the lens of governmentality, drawing principally on the work of Nikolas Rose (Miller and Rose, 1990, 2008; Rose, 1996, 2017; Rose et al., 2006). Employing an empirical analysis of Neighbourhood Planning - a community-led, land-use planning initiative introduced via the UK' 2011 Localism Act - the paper explores how 'responsible' citizens are called up and mobilised towards particular governmental ends. This traces the emergence of localism under New Labour before the emergence of present attempts to link "localism and the need for growth" (Stanier, 2014: 1) via spatially-based technologies predicated on concepts of community control, competition and financial incentives.

The governmentality literature displays a tendency to focus on the abstract, overlooking the messiness of actual attempts to govern, and the extent to which political rationalities are contested

\footnotetext{
${ }^{1}$ Localism has developed differently in the constituent countries of the UK. Localist initiatives play out within particular state-society relations, creating significant differentiation in institutional governance arrangements and associated executive, legislative and financial powers (see Pemberton, 2017). This paper focuses specifically on England as the only part of the UK where Neighbourhood Planning is available to communities.
} 
rather than all-powerful (Li, 2007). The paper seeks to address these oversights by exploring how governmental technologies play out in practice, and in particular where attempts to subjectify populations and realign subjects' agency toward governmental aims fall short of their stated ambitions. To do so, the rationalities of post-2010 localism are questioned, in particular: how selective spatial imaginaries have been mobilised; the role of conflict in planning and politics; the framing of state-society relations; and the relative positions of expert and local knowledges in participatory settings. In concluding, it is argued that the fault-lines and misrepresentations found within these rationalities go some way to explaining the emergence of "interstitial spaces of hope" for genuine expressions of community agency within the confines "gradually tightening governmentalities" (Williams et al., 2014: 2805).

\section{Localism as Governmentality}

Through his analysis of governmentality (gouvernmentalité), Foucault (1991) sought to explore how power operates in modern societies through the creation of discourses, subjects and institutions. This explored how governments and others shape the' conduct of conduct', managing increasingly disparate populations by deploying particular forms of knowledge and creating subjectivities through which government strategies and programmes can be implemented. Such forms of knowledge are shaped by political rationalities, or:

... practices for the formulation and justification of idealized schemata for representing reality, analysing it and rectifying it - as a kind of intellectual machinery or apparatus for rendering reality thinkable in such a way that it is amenable to political programming (Rose, 1996: 42)

Localism can be understood as one such rationality - a lens through which to represent, assess and intervene in particularly spatial form of governance. Rose (2017) argues that political rationalities have three central characteristics, which we can apply here to localism (see also Miller and Rose, 2008). First, they have a moral form, "a belief in the proper ends of the government of conduct ... and in the proper distribution of powers and duties between authorities in that enterprise" (Rose, 
2017: 311). The turn to localism witnessed in the UK since the 1990s can be read as a 'moral' response to perceived alienation of local communities precipitated by a globalised world increasingly defined by marketisation and presided over by centralised states (Hickson, 2013). Successive administrations have therefore sought to inculcate a sense of renewed local identity by recasting traditional communities as sites of social and political action where citizens might regain control over their own lives:

The government wants to put power back in the hands of local residents, employees and business, councils and civic leaders - those who know best the needs of their local areas ... No one has to do it, if they don't want to. But we think that lots of people will want to take the opportunity, to influence the future of the place where they live or work. (DCLG, 2012a: 3)

The 'proper' distribution of power is made explicit throughout localist discourse where "distant government officials" (Conservative Party, 2009: 2) are upbraided in favour of local people who "know best" (DCLG, 2012a: 3). Since 2010, choice and opportunity have been central to the morality of localism, where the right to have a say in local governance is elided with the responsibility to "take control" (Conservative Party, 2010: 73).

Second, rationalities have an epistemological character: they are "based on a particular conception of the domain to be governed ... and of the persons over whom government is to be exercised ... a resource to be exploited, elements of a population to be managed" (Rose, 2017: 311). The inherently spatial nature of localism provides fertile ground for governments seeking to evoke particular images and ideas that render reality knowable and thereby governable. In this vein, Tait and Inch (2016: 178-181) have explored "the romantic idea of the village community" as a core spatial imaginary deployed by post-2010 localism, invoking deep-seated within Conservative political thought, drawing on inter alia Burke's little platoons and de Tocqueville's civil associations. Such language is ambivalent towards two decades of research on place and community, preferring to conjure up a nation of autonomous and internally homogeneous localities (Clarke and Cochrane, 2013: 14). 
Presenting 'the local' as free from the political conflicts found at other spatial scales is central to localism's logic, which leads to the third characteristic of political rationalities, namely that they are articulated in a distinctive idiom - a language that is more than rhetoric, "an apparatus ${ }^{2}$ for rendering reality thinkable in such a way that it is amenable to political deliberations" however irrational and incoherent such language may be (Rose, 2017: 311). Perhaps the defining feature of localism's idiom since 2010 lies in its antagonism toward the state and a corresponding valorisation of middle-class voluntarism and social responsibility (Featherstone et al., 2012). This is most noticeable in the juxtaposition between 'big government' and the Big Society that again adopts the language of opportunity:

Government has failed to adapt to this new world of power and opportunity for people and communities ... all too often decisions which affect local communities are taken by remote officials in Whitehall departments and unelected quangos and then simply implemented, with limited powers of variation, by officials in town halls. (Conservative Party, 2009: 4)

In addition to contrasting local control with distant bureaucracy, post-2010 localism has tried to create the conditions for the exercise of choice in 'responsible' ways by appealing to individuals' rational self-interest. Localist initiatives have been laced with financial instruments (Inch et al., 2020) and couched in terms associated with market-based liberalism (Davoudi and Madanipour, 2013). This can be seen through the use of the funding regimes that anticipate both local government and local communities responding to financial incentives (see discussion of the Community Infrastructure Levy below) that nudge localities toward meeting government objectives. Bundling up opportunities for local control with funding programmes in this way equates empowerment with participation in the market, invoking the neoliberal project's attempts

\footnotetext{
${ }^{2}$ A key concept in Foucault's writing from the mid-1970s onwards, dispositif (commonly translated as 'apparatus') denotes "a thoroughly heterogeneous ensemble consisting of discourses, institutions, architectural forms, regulatory decisions, laws, administrative measures, scientific statements, philosophical, moral and philanthropic propositions - in short, the said as much as the unsaid. Such are the elements of the apparatus. The apparatus itself is the system of relations that can be established between these elements" (Foucault, 1977: 194). It is arguable whether the translation 'apparatus' sufficiently captures dispositif as a particular kind of (normalising) force that permeates our "customs, habits, ways of acting and thinking" (Foucault, 1991: 93), nonetheless, in light of the empirical components of the paper, the discussion here follows Rose's focus on how in order to become governmental, rationalities (or "styles of thought") must become technical, that is, be linked to governmental technologies (see Miller and Rose, 1990; Rose, 2017).
} 
to conflate social and economic realms (see Lemke, 2019). Concepts such as social inclusion, solidarity and equality are conspicuous by their absence in the language of post-2010 localism (see discussion of New Labour's New Localism below). Instead, social action is subsumed within a "responsibility agenda" (Conservative Party, 2009) that orders the messiness of social relations through legal and technical programmes that emphasise financial incentives and material rewards. As such" the social 'is reconfigured as "a series individuals who operate within a framework of quasi-markets to provide services and expertise" (Davoudi and Madanipour, 2013: 559). In this way localism is "rendered technical" ( $\mathrm{Li}, 2007: 7)$ and thereby considered governmental:

... to become governmental, such thought ... [has] to become technical, to link itself to governmental technologies: the complex of mundane programmes, calculations, techniques, apparatuses, documents and procedures through which authorities seek to embody and give effect to governmental ambitions. Political thought becomes governmental when it can link itself to a technology that seems to provide a means of realization (Rose, 2017: 314)

Governmental technologies, made possible by the particular configuration of localism's rationalities, refer to the "strategies, techniques and procedures through which different authorities seek to enact programmes of government in relation to the materials and forces to hand and the resistances and oppositions anticipated or encountered" (Rose, 1996: 43). The next section provides an account of the shift from the technologies employed under the auspices of New Labour's 'New Localism' (1997-2010) to those employed by the Conservative-led administrations since 2010.

\section{Technologies of Government: From Managerial to Austerity Localism}

In order to understand the localism agenda pursued in England since 2010, it is necessary to explore its antecedents witnessed under the New Labour premierships of Tony Blair (1997-2007) and Gordon Brown (2007-2010). This seeks to show the trajectory of area-based initiatives (ABIs) implemented, the disparate aims to which localism can be put, and how prevailing rationalities 
and how we think about governing aids in the production of technologies through which we are governed and we govern ourselves (Davoudi and Madanipour, 2013).

When the Conservative-Liberal Democrat Coalition came to power in 2010, it sought to continue the positive connotations concerning local action fostered by New Labour's 'New Localism' by introducing its own localism agenda that prioritised economic growth and underscored the notion of autonomy (Conservative Party, 2010a; Lupton, 2013). The New Localism had foregrounded accountability and legitimacy through sustainable, resilient and empowered communities (DCLG, 2008), and whilst these rhetorical aspirations did not fundamentally change in 2010, the means of delivery were radically altered. The funding schemes of the New Labour period were discontinued (notably the National Strategy for Neighbourhood Renewal, New Deal for Communities, Neighbourhood Renewal Fund, Local Area Agreements and Housing Market Renewal), and replaced with a raft of localist initiatives focused on stimulating economic growth through the rescaling and reform of the planning system, the Regional Growth Fund, and Devolution Deals. The last of these featured a 'menu 'of powers to be individually negotiated between devolved areas and the UK Treasury; this move to bespoke 'deals 'marked a significant departure from New Labour's promise to eradicate 'postcode lotteries' through targeted intervention.

Following its election in 1997, New Labour had sought to rekindle the tradition of "mutualism, localism and devolution" (Blair, 2002) providing communities with "choice and voice" over local services. Democratic renewal was to be achieved through forms of networked community governance creating new partnerships between the state, the Third Sector and the private sector. These partnerships were parcelled up in a series of ABIs such as the Single Regeneration Budget, New Deal for Communities and Local Strategic Partnerships that variously sought to intervene in a range of 'wicked problems 'in the most deprived neighbourhoods primarily under the banner of regeneration (Lowndes and Sullivan, 2008). Techniques of reflexive risk calculation, quantification and benchmarking became common place, allowing localist programmes to be assessed against centrally defined parameters (Dean, 2010). Davoudi and Madanipour (2013: 555) classed this proliferation of techniques as technologies of performance, encapsulating strategies 
that seek to subsume the professional expertise developed under the welfare state into new formal calculative, and therefore governable, regimes.

The plethora of ABIs introduced went hand in hand with New Labour's 'modernisation' agenda (Newman, 2001), which sought to restructure public services in line with New Public Management principles of efficiency, competition and the citizen-customer. This was to be achieved through auditing practices, target-setting and performance indicators through which the central state could monitor and control the local apparatus, devolving limited powers to Local Authorities through the principle of 'earned autonomy' - rewarding good performance and imposing penalties for missed targets. Over time, greater prominence was given to economic outcomes, particularly under Gordon Brown's premiership. Following a Treasury review in 2007, 'neighbourhood renewal' was effectively subsumed within a new Regeneration Framework that focused on improving economic performance, combating worklessness, and creating sustainable places where businesses want to invest (DCLG, 2009; Lupton, 2013).

For some, New Labour's principle of ‘double devolution' - shifting power first to local government and subsequently to communities themselves - was deemed to have introduced a new democratic culture that could both stimulate and legitimise new forms of local action and usher in a new formulation of centre-local relations (Barnes et al., 2007). For others, including early proponents such as Stoker (2011), the top-down culture dominated by central guidance and extensive auditing requirements had constrained local ownership and resulted in a highly managerialist form of localism - ultimately precluding an agenda that had any political bite. For governmentality theorists, the democratic character of the political sphere had been increasingly eroded by the encroaching imposition of market forces that set the 'rules of the game', such that the social inclusion ethos of the early New Labour period came to be precluded by economic considerations, in line with the a predominantly neoliberal economic order (Swyngedouw, 2005). 
Following the 2010 General Election, 'the local' continued to be promoted as a key site of social and political action with decentralisation as a key pillar of Coalition's Big Society agenda ${ }^{3}$. As numerous commentaries have made clear, the Big Society was widely regarded as an ideological smokescreen for the neoliberal priorities of retrenchment and marketisation that were instituted alongside a shallow form of communitarianism that embraced the progressive narratives of participation, community and partnership (Featherstone et al., 2012; Allmendinger and Haughton, 2012; Lowndes and Pratchett, 2012; Tait and Inch, 2016). The decentralisation agenda involved repackaging the New Localism through a combination of libertarian paternalism drawn from One Nation Conservatism, long-standing traditions of voluntarism and social action, and the growth imperative (Lupton, 2013). In turn, these were mediated by the Liberal Democrat 'liberalism-cumcommunity 'tradition (Lowndes and Pratchett, 2012); however, of more consequence for this new articulation of localism was the coincident austerity agenda, which was particularly keenly felt at the local level. The voluntary sector, communities, and the private sector were expected to fill the space vacated by a retrenched local state, creating their own governance networks and promoting growth within a functional economic space defined by the market.

This shift saw communities move from integral to 'turning around' neighbourhoods with concentrated social ills (SEU, 1998), to sites of aspirational 'innovation and entrepreneurship', able to control local services and respond to financial incentives (notably the Community Infrastructure Levy - see below) designed to persuade communities to act as drivers of progress (Conservative Party, 2010b). This juncture was marked by a policy paper that established a menu of activities that localities could draw on, replacing New Labour's targeted approach with a first come, first served model (DCLG, 2011). Concurrently, the agreed framework of national minimum standards - previously considered crucial to preventing localism from reinforcing of place-based inequalities (Corry and Stoker, 2002; Stoker, 2004) - was abandoned as various auditing regimes were abolished (notably Comprehensive Area Assessments, Local Area

\footnotetext{
${ }^{3}$ Decentralisation was one of three strands to the Big Society agenda - alongside increased social action and 'opening up 'public services. It was also the most durable and led to the 2011 Localism Act whilst the Big Society was slowly dropped from the political lexicon.
} 
Agreements, the Standards Board for England, the National Indicator Set, and the Audit Commission). This made it difficult, if not impossible, for localities to be benchmarked or compared, allowing communities to be considered in isolation and avoiding engagement with the marked inequalities that exist within and between places (Lowndes and Pratchett, 2012).

At the same time, the planning system was being fundamentally reformed through the revocation of the Regional Spatial Strategies (RSS) that had been in place since 2004. Regional planning had fallen foul of the "seemingly intractable struggle between strong strategic planning ('the greater good') and vocal (political and community) interests within local democracy" (McGuinness and Mawson, 2017: 299). In their place, a 'Duty to Cooperate' between adjoining planning authorities was introduced. Evidence suggests that the RSS has failed to fill the strategic planning void (McGuinness and Mawson, 2017), whilst the shift from regional to local planning can be seen as the latest in a long line of attempts to secure an institutional or spatial fix for sub-national governance, one that is inevitably caught up in a field of tensions constituted by dualities of local/strategic priorities, top down/bottom up control, and competing expert/local knowledges (Wargent et al., 2020b). The new localist approach introduced a range of governance experiments such as Local Enterprise Partnerships and City and Devolution Deals, a suite of Community Rights, as well as and the formal recognition of planning at the neighbourhood scale.

Many of these new powers sought to bypass local government by empowering communities to take public assets into local ownership, bid for local services and have a greater say over land-use planning. This reflected a shift towards technologies of agency, or techniques that seek to liberate individual freedoms and redeploy community efforts in ways that meet governmental objectives (Dean, 2010). Despite the abolition of national indicators and audit trails in line with the neoliberal desire for a smaller state, the technologies of performance prevalent during New Labour's tenure were not entirely abandoned, but rather became less visible. In short, the transition witnessed from 2010 has seen a "shift of emphasis from government technologies of performance to technologies of agency, without abandoning the former" (Davoudi and Madanipour, 2013: 559). The result is an anti-statist articulation of 'austerity localism' (Featherstone et al., 2012) with local government's 
purpose recast as removing barriers to local action and aligning incentives with the promotion of economic growth at the expense of addressing spatial inequalities.

Post-2010 localism can therefore be understood as combination of technologies that seek to summon up and harness community capacity, whilst continuing to regulate this agency through the use of targets and financial incentives. In this schema, communities are not seen as pre-determined legal, social or political entities, rather they are constantly (re-)constituted, (re-)defined and (re)categorised within given constructed identities often predicated on a lack of a particular characteristic such as for example worklessness or homelessness (Cruikshank, 1999). Subjectified populations are then deployed toward governmental ends. Whereas New Labour's localism agenda identified a deficit of social participation and foregrounded social exclusion (SEU, 2001), since 2010 communities have been framed as bereft of opportunity, lacking incentives for local action, and without "real local democracy" (Conservative Party, 2009: 3).

\section{Methods}

The remainder of this paper explores local actors' perceptions of Neighbourhood Planning ${ }^{4}$ across England. Primary data were collected between 2015 and 2018 via semi-structured interviews conducted with local residents ( $\mathrm{n}=51$ ), Local Planning Authority (LPA) officers involved in supporting Neighbourhood Planning $(\mathrm{n}=16)$ and planning consultants $(\mathrm{n}=3)$ all of whom had helped deliver multiple plans. Participants were selected using information-oriented selection, using contextual information known to the researcher from a previous study (Parker et al., 2014). Participants representing 'typical 'neighbourhood plans were selected, avoiding communities that had either experienced exceptional levels of conflict (to the extent that the process was jeopardised) or who had outsourced significant parts of their plan to consultants. Consequently, all

\footnotetext{
${ }^{4}$ Neighbourhood Planning encapsulated Neighbourhood Development Plans, Neighbourhood Development Orders and Community Right to Build Orders. The focus here is on the Neighbourhood Development Plans (or simply Neighbourhood Plans) as the most comprehensive by far the most popular tool available.
} 
community participants represented successful, though not necessarily completed, Neighbourhood Plans. Further research is required into stalled and abandoned plans. The sample was split between parished $(n=30)$ and unparished $(n=21)$ neighbourhoods - in the latter case a Neighbourhood Forum can be formed by a minimum of 21 residents.

\section{Local Perspectives of Neighbourhood Planning}

With over 2,600 participating communities throughout England, Neighbourhood Planning is the flagship policy of post-2010 localism agenda. The policy grants communities the right to produce a statutory, land-use plan which can guide development in their neighbourhood, typically for a period of 15 years. Plans must pass certain light-touch 'basic conditions 'and must have regard to national planning policies and conform to local strategic policies to the satisfaction of an independent examiner. Crucially this means that Plans cannot promote less development than set out by higher tier policies. Plans must also receive the support of a least $50 \%$ of the community at a referendum. Communities are able to access government grants administered via Locality, a social enterprise that operates alongside AECOM to deliver the government's Neighbourhood Planning support package. As of 2018 , the basic grant stands at $£ 9,000$, although this can rise to $£ 17,000$ in certain instances, such as:where neighbourhoods have a population over 25,000 people; where Plans include design codes; or where Plans are produced by either a group of councils or by local businesses rather residents (as of late 2019, less than 1\% of Plans were business-led).

Additional funding is also available to communities who seek to allocating sites for housing. This recognises that allocating sites can be an onerous task for local communities (who may not possess planning expertise). It also seeks to nudge communities towards accepting new development, disclosing Neighbourhood Planning's core purpose: to increase and speed up the delivery of housing (see Figure 1). The policy is predicated on the belief that residents understand their communities better than remote officials, and when given greater control will be less likely to oppose new development (Sturzaker, 2011). 


\section{Figure 1: DCLG's Neighbourhood Planning Policy Model}

\section{INSERT HERE}

Source: Stanier (2014: 13).

\section{Anti-statist spatial imaginaries}

From the introduction of the first 'Frontrunner' Plans in December 2010 by the then Department for Communities and Local Government (DCLG) ${ }^{5}$, Neighbourhood Planning has been central to reforms designed to shift a "wholly negative and adversarial" planning system towards one "rooted in civic engagement and collaborative democracy" (Conservative Party, 2010a: 1). Unlike New Labour's ABIs that sought to address social exclusion by targeting deprived communities, Neighbourhood Planning allowed self-selecting communities the opportunity to claim "a share in local growth" on a first come, first served basis (Conservative Party, 2009: 9). The language of opportunity and community control has been central to post-2010 localism's idiom, but have sat uncomfortably alongside the desire to promote a "collaborative democracy". The same discourses having been laced with more combative, anti-statist imagery, that frames local people as at odds with local government:

... by making local government more accountable and bringing people closer to the levers of power we can start to restore the trust that's been lost in our political system. If voters want to see something done in their area, they'll be able to force it on to the agenda. (Foreword by David Cameron, Conservative Party, 2009: 1)

A raft of Conservative Party policy papers released in run up to the 2010 General Election framed local communities as being denied the incentives and opportunity to pursue local action. The blame for such powerlessness was laid at the feet of "distant bureaucrats" (Conservative Party,

\footnotetext{
${ }^{5}$ DCLG was renamed the Ministry of Housing, Communities and Local Government (MHCLG) in January 2018 by then Prime Minister Theresa May to reflect a renewed political emphasis on housing.
} 
2010b: 75) and" sprawling ... distant and remote" forms of regional and local government (Conservative Party, 2009: 28). Disenfranchised communities without "real local democracy" (Conservative Party, 2009: 3) were juxtaposed with normative ideals of citizenship with "individuals and families taking responsibility" (Conservative Party 2010a: 12). In the case of Neighbourhood Planning, communities were encouraged to define their own neighbourhood to reflect functional geographies and a local sense of place (although the majority of communities in parished areas have adhered to existing administrative boundaries). From its inception therefore post-2010 localism has been expressed in an idiom that is embraces self-determination at the expense of the role of local state.

Antipathy towards state 'agendas 'has been long been recognised as a key rationale for the passing of regulatory competences from public bodies to 'responsible 'and 'rational 'individuals (Lemke, 2001). Distrust of local government has been reflected in many Neighbourhood Planning communities where the prospect of local control was contrasted with unsatisfactory prior experiences of engaging with their Local Authority (LA), resulting in scepticism toward greater partnership working:

I don't think I'd want someone from the council to help us ... because I don't trust that they wouldn't have another agenda ... which may not square with the way our community works ... although they say they support what we do, they don't actually support in action (Community Interview 14)

The council will always have their own agenda, which might not be a bad agenda, but it will be an agenda ... They're maybe not conscious of doing it, they're trying to steer us into things ... I don't think they're being deliberately unhelpful, but they've caused us some serious extra work ... they played it very close to their chest and it has caused us a few problems (Community Interview 12)

This contrasts sharply with New Labour's advocacy of partnership between the state and the Third Sector through double devolution. This contrast highlights an inherent tension involved in integrating 'community-led' policy within the legal and regulatory frameworks necessarily structured by the (local) state. Indeed the Conservative Party's early vision for a reformed planning system saw a closer relationship between planning authorities and communities. A Green Paper published in February 2010 entitled Open Source Planning argued for a system of plans developed 
from the ground up, with a central role for planning authorities in helping communities develop their visions:

... we will expect to see, at a minimum: the evolution of the plan starting at 'ground level 'in neighbourhoods with every single resident of the neighbourhood approached to take part ... [and] a role for the planning authority itself in helping neighbourhoods to develop their visions and in brokering a rational and coherent plan for the area as a whole, on the basis of negotiation with each of the neighbourhoods and with all the relevant public agencies responsible for infrastructure and the environment.

(Conservative Party, 2010a: 8)

This is evocative of the municipal neighbourhood planning model typically adopted in the US where citizens develop their own neighbourhood plans in conjunction with local planning departments (Rohe, 2009: 222-225). At the time Open Source was published however, the UK was still reeling in the wake of the Global Financial Crisis, and a more dominant political message was being promulgated, namely the disempowering effects of a profligate 'big government'. The deleterious effects of bureaucratic dirigisme were easily contrasted with "the romantic idea of the village community" (Tait and Inch, 2016: 176-181). As a consequence, the model of Neighbourhood Planning that resulted saw the LA role stripped back to an amorphous 'Duty to Support' communities. This established a zero-sum understanding of state-society relations where communities could simply step up and deliver effective planning in the wake of an enfeebled local government. As we have seen, the spatial imaginaries invoked not only overlooked the role of the state but were openly antagonistic to it, introducing a tension that was reflected in local views:

$\ldots$ it pits the community against the LA, it's almost an aggressive system ... it's saying there's no point trying to reconcile the LA with their local communities in the planning context, so let's pit them against each other, let's say that the community can strip out a decision of the council and come up with their own planning policies. (Community Interview 1)

Yet despite such antagonism, research has shown the benefits of co-production between local government and communities (Parker et al., 2017) ${ }^{6}$. Such contradictions reflect the creative

\footnotetext{
${ }^{6}$ Co-production is a contested term that continues to generate a wealth of research literature including a consistent critique of whether 'genuine 'co-production is possible given inherent asymmetries of power. It is broadly defined here as a process by which different actors utilise each other's resources to create a mutually desired output involving processes of reciprocal learning and understanding (Parker et al., 2017: 453). For a more detailed discussion see Watson (2014).
} 
tensions described in the wider Neighbourhood Planning literature (Brownill and Bradley, 2017), but also challenge the belief that the usual conflicts associated with planning and development can be circumvented simply by reforming the manner of decision-making (Gallent et al., 2013). As one participant reflected: "if there was a major conflict, the Neighbourhood Plan doesn't really allow for a revolution does it?" (Community Interview 32).

\section{Bracketing out conflict}

Some participants went further and argued that the inability to explore conflict within new participatory spaces - such as being unable to contest housing allocations - as "politics at its most controlling" (Community Interview 2). Such tensions contradict the need for "reduced politicisation" (Stanier, 2014: 13). The lack of engagement with the inherently political and contested nature of planning has proven problematic; in some instances the inability of communities to explore contentious issues and counteract strategic policies has led groups to leave the process. The primacy of afforded to housing growth has resulted in a regulatory framework that seeks to bracket out the constitutive and productive role that conflict plays in democratic practice (Mouffe, 2005). This is despite the literal and figurative boundary work done by Neighbourhood Planning that produces democratic spaces that are highly conducive to forming political identities through attachments to place: following the work of Mouffe, it has been argued that the creation of such "we/they" identities between conflicting perspectives is the most realistic way to productively harness the inherently conflictual nature of planning (Bradley, 2015; Parker et al., 2017).

Early rhetoric set out a desire for local people "to specify what kind of development and use of land they want to see in their area" through a planning system based on the "values of transparency and free access" (Conservative Party, 2010a: 1-2) and facilitated by a "light touch" approach to regulation (DCLG, 2012b: 6). Yet as Neighbourhood Planning developed, the policy that materialised via the 2011 Localism Act was far more constrained. Neighbourhood Plans were 
ultimately required to be in conformity with national planning policy and the strategic vision for the wider area set by the LPA (principally the Local Plan). This has meant that communities cannot accept less development than is already set out by their LPA. The need for such 'conformity' has consistently remained a core complaint of participants:

We're not NIMBYs and not anti-development, but what power have they given us if, fundamentally, we can't decide how many new houses are going to be built? (Community Interview 42)

Despite claims about far-reaching local powers, Neighbourhood Planning ultimately devolves managerial, rather than political, power (i.e. how to meet targets not what targets should be met). This has left post-2010 localism open to critique that it denies even the preconditions for politics by replacing its content - debating, contesting, compromising and so on - with markets, financial incentives, and mechanisms of direct democracy (Clarke and Cochrane, 2013: 16-17).

The limited role for local government has pushed the responsibility to interpret the regulations down to communities themselves. Central to this has been the scope of permissible action available to communities and the issue of conformity with higher tier policies is not always clear cut, not least where Local and Neighbourhood Plans are being produced simultaneously (Brownill, 2017). What can and cannot be pursued through a Neighbourhood Plan has proved a flash point for confrontation within communities, where consultation exercises often "opens up a can of worms" (Community Interview, 40) by highlighting concerns that are beyond the scope of Neighbourhood Planning to address. With respect to housing, this has led to the majority of Plans accepting the bare minimum of housing allocations required (Lichfields, 2018), whilst concentrating on other aspirations such as protecting green spaces, establishing community projects and developing affordable housing schemes.

The process of developing a Neighbourhood Plan can also stir up existing, often long-held, local grievances - and in a number of cases this has led to process being suspended indefinitely. Such tensions must be navigated by communities themselves: 
... there is potential for conflict, the Chair manages it very well I think but you know you have people who take their stance and people have strong feelings ... I have to say of the way people act I'm surprised anything ever gets done. You have to focus on something that you can do, because if you try to do everything that you possible could for the community there would be no end to it. (Community Interview 3 )

That localities are plural and contested is by no means a new discovery, yet as Tait and Inch (2016) and others have explored, post-2010 localism's idiom evokes an image of 'the local' as homogenous, conflict-free, and typically rural. Indeed Neighbourhood Planning can be seen as an extension of more explicitly rural (non-statutory) initiatives such as Parish Plans and Village Design Statements (DEFRA, 2013). Little attention has been paid to the heterogeneity of communities likely to be attracted to the new statutory powers: this has proved problematic for urban communities where a range of diversities are more common:

I've worked in community development for 20 years and I can tell you one of the first things DCLG need to do is rewrite their guidance in a way that inner city communities can understand. We have transient populations and not everyone here is a retired barrister (Community Interview 18)

... the same regulations apply to underpopulated, suburban, middle class communities and inner city, deprived, completely opposite type communities ... there's a need for a bit of differentiation to made. Definitely I think the problems are very different ... the process hasn't been thought through in a way that allows communities like ours, you know that are quite deprived, to participate in the same way. The key thing is how it's expressed, DCLG want more areas like ours involved, then they need to address some of the phrasing ... it's a very complex and jargonistic process, it's opaque and bureaucratic ... There's also a need to recognised an entirely different set of social circumstances in some communities. When they were talking about the Big Society agenda - I thought precisely which communities have you ever been in? (Community Interview 2)

In urban areas, particular problems have arisen where communities have struggled to reach consensus over neighbourhood boundaries and the composition of the Neighbourhood Forum, stirring existing tensions and creating new dividing lines (Colomb, 2017). Overlooking these barriers and construing communities as homogeneous is central to the epistemological character of post-2010 localism's rationality, presenting a particular idea of the domain and subjects to be governed (Rose, 2017: 311). In this instance, 'the local' and the responsible, capable, and willing residents found there are defined construed as free from the political conflicts found at other spatial scales, and therefore well placed to wield new these new powers. By deny communities 
their radical plurality and ignoring contested political claims has contradicted the desire for a reinvigoration of local politics by hemming in its participants (Williams et al., 2014; Parker et al., 2017).

How subjects are created in particular places at particular times is central to the governmentality approach, providing insights into how states govern. Given the idealised vision of communities invoked, it is perhaps not surprising that participating Neighbourhood Planning communities are disproportionately rural, parished and affluent (Parker and Salter, 2016). Such communities typically retain (or can procure) the professional skills required to create a Neighbourhood Plan, whereas in more deprived communities the need for professional expertise is a significant barrier to participation:

I'm not sure giving communities the right to make their own plans without input from the Council other than to say whether is legal or not, is necessarily the way forward and I think it does either mean that places are relying on having people that have extensive knowledge of the planning system from their own professional background or failing that private planning consultancies - and that opens up the whole issue of inequality (Community Interview 1)

These high barriers have resulted in a distinctly skilled, middle-class population being 'called up ' to engage with the planning system. As Lemke (2001: 213 - emphasis added) explains, positing that desired social realities already exist is a central strategy of neoliberalism:

... the theoretical strength of the concept of governmentality consists of the fact that it construes neo-liberalism not just as ideological rhetoric or as a political-economic reality, but above all as a political project that endeavours to create a social reality that it suggests already exists. Neo-liberalism is a political rationality that tries to render the social domain economic and to link a reduction in (welfare) state services and security systems to the increasing call for 'personal responsibility 'and 'selfcare'.

The selective spatial imaginary envisaged for Neighbourhood Planning described above is simultaneously an attempt to 'call up' such communities and create a viable local governance structures able to deliver growth. As the policy model demonstrates (Figure 1), it was assumed that such communities would consent to development due to an alignment of financial incentives such as the Community Infrastructure Levy (CIL). The CIL is a charge levied by LAs on new 
development $^{7}$; neighbourhoods that produce Plans receive a greater proportion these receipts $(25 \%$ rather than the base level of 15\%). Despite this inducement, there is limited evidence that participating communities are more accepting of local development and agreeing to more housing. Community interviews described the CIL uplift as a "bung" (Community Interview 32) or "bribe" (Community Interview 7), and only one respondent cited additional monies as a motivating factor a Forum in London that stood to gain a significant sum given the level of slated development in their neighbourhood. Indeed evidence commissioned by MHCLG suggests that financial inducements are unlikely to shift local attitudes toward housing development (Inch et al., 2020).

This begs the question whether successfully 'calling up' skilled communities has resulted in Neighbourhood Planning delivering on its growth ambitions. To date there have been two attempts made to quantify the housing growth delivered. The first was based on a sample of 39 plans, indicated a $10 \%$ increase in the housing numbers produced by Neighbourhood Plans compared to the relevant Local Plan (DCLG, 2016). Calculating net additionality is extremely difficult since many sites come forward as both Neighbourhood and Local Plans are emerging; DCLG's adopted methodology has been questioned (including in a High Court judgement) since the sample included sites that had already been granted planning permission. A subsequent analysis of 330 plans by Lichfields (2018) only considered 'new' allocations and established a $0.8 \%$ increase in housing numbers compared to the Local Plan process.

The evidence of this study suggests that where communities engage in housing issues, they seek to it tailor incoming development to local needs, by breaking up larger sites, changing densities patterns and creating affordable homes policies. Research by Parker et al. (2017) suggests that many communities are adopting anticipatory conservative behaviours - limiting the scope of their

\footnotetext{
${ }^{7}$ The CIL rate is set by each charging authority, allowing LAs to raise funds to help deliver infrastructure to support the development of the area. CIL receipts are passed straight to Parish and Town Councils where development has taken place, however in the case of Neighbourhood Forums the CIL is retained by the charging authority and spent in consultation with the Forum. By setting competitive rates, LAs can attract new developments. Further inducements made to LAs to deliver growth include the New Homes Bonus (where central government matches council tax receipts raised from new homes for a period of six years) and reforms designed to allow LAs to retain $100 \%$ of Business Rates collected locally.
} 
plans and shying away from innovative policies that might be struck out during independent examination. Such instrumental attitudes amongst communities keen to simply "get it done" (Community Interview 30) have been driven by the highly burdensome nature of the process, with communities having to jump through regulatory hoops and penetrate the legal-technical language of the planning system. The statutory footing of Neighbourhood Plans is at once both a significant attraction for local communities, but also a barrier as it requires community aspirations to be translated into the technical language of planning policy and be robust enough to withstand legal challenge (often brought by housing developers). This belies a further tension inherent to the planning process: in seeking to carve out a space for community action within the formal planning system, Neighbourhood Plans have provided legal weight to community views, the demands of which have created a technical, ritualised and bounded process that has undermined the early rhetoric of community control.

\section{Local and expert knowledges}

The considerable technical burdens involved in creating planning policies have driven the majority communities into the hands of consultants. Approximately 7 in 10 communities have employed consultants in varying capacities, from advisory roles, conducting consultation events, producing evidence, and in some cases undertaking the process entirely (Wargent and Parker, 2018). The majority view of community participants was that consultants were a necessary resource for communities who were inexperienced in the workings of the planning system, required to "translate community aspirations into planning speak" (Community Interview 22). Despite representing necessary sources of knowledge for communities, some participants noted their concerns that consultants' advice acted to curtail innovation and community ambition as much as facilitate community ownership over the process. One consultant, now a specialist in Neighbourhood Planning, explained the relationship between himself and the community: 
... one of the steering group committee said I'm really disappointed we're not saying anything about traffic in this plan, and I said: "we can say that, but do you know how are you going to do this? How does that transpose into a planning policy? Will we get it through examination?" He said: "I know but we had such good ideas!" We had a really good discussion but at the end of the day I had to say I don't think I can get that through an examination, and as soon as I say that they have to back off. My job is to get this bloody thing through examination, I can't promise the world and then have it fail, then everybody's wasted their money (Consultant Interview 1)

Although little is known about consultants' ethical and professional codes of conduct, their practices, or their impact on local outcomes via the planning system (Wargent et al., 2020a), within the context of Neighbourhood Planning, consultants often appear to moderate community aspirations by providing 'objectivity', as a second consultant described:

... [one community] just want someone with our skills to write it up in a way that will get through independent examination and that's feasible. I am going to be a a filter between what they want me to write and what I actually write, I will filter out anything that won't get out the examination ... I would strongly advise that at some point that external, professional, technical advice be used either to filter or just to write up, or to moderate, or whatever word you want to use - with that external person there's more chance that what you're going to get is more of an objective view than giving it to the local person (Consultant Interview 3)

This reveals the relative positions of local and expert knowledges, with the former requiring moderation or rescripting to fit the expectations of the latter. The reliance on professional expertise also belies the assumption that communities can simply bypass local government and "take control" of local assets, competencies and services traditionally provided by the state (DCLG, 2013: 4). In addition to translating community views, consultants have played a key role in providing the evidence base required for Neighbourhood Plans. Local Authority interviewees questioned the ability of communities to identify the types of evidence required, and communities themselves argued the levels of evidence were "overwhelming" (Community Interview 11) and “an impossibility without experts guiding us" (Community Interview 21).

The technocratic demands of Neighbourhood Planning raise questions around advocacy, who is representing communities and how, alongside questions of equity given the high cost of using consultants. The considerable time and effort required to project manage a Neighbourhood Plan has fed into instrumental behaviours with many communities attempting to "get their money's 
worth" (Community Interview 33) from consultants, creating a need to expedite crucial

components of political action such as debate, discovery, contestation and compromise. As one

consultant described, suppressing confrontation was key to engaging with the wider community:

The first sense we get at each event is confrontation ... each event starts out angry and so we tend to have the first 10 or 15 minutes dedicated to venting that anger ... it tends to be the LA that residents hold as the main culprit in whatever's happening. So it's just a quick time ... to put across their grievances about the development, and for the council to say 'yes we understand 'but outline the background as to why [development is] happening: it's from a national level it's got to be done. And then we make quite clear that the events we run are not intended to stop development. (Consultant Interview 2)

As seen above, the pro-growth orientation of Neighbourhood Planning has proved a flashpoint within communities. Many participants indicated that they were oversold the plenipotentiary powers on offer, finding the process "very empowering, until it's not" (Community Interview 16) reflecting the fact that many communities' aspirations go beyond traditional land-use planning:

... you don't feel empowered to say "oh well we'll stop that development from happening" - our neighbouring ward were trying to stop something from happening, now they've had this terrible shock because they can't ... I think communities have been oversold what they can do if you want my honest opinion. I think people love the idea of the community taking control because they want to do something that the powers that be don't want them to do ... so the principle is brilliant, it's just it doesn't seem to always work out in practice (Community Interview 4)

I think [central government] have been misguided in stating that Neighbourhood Planning will allow local people to control their areas without making it clear that the real aim is to increase housing not prevent it - and that it only relates to planning policy, not all the things that are of real local concern to people (LPA Interview 9).

The limited and episodic nature of empowerment experienced by participants indicates that Neighbourhood Planning has failed to empower communities on their own terms. The early rhetoric of community control raised expectations, resulting in disillusionment later on:

I've become very fatalistic about the whole thing. I was at a planning meeting recently talking about the Forum's work when I was very abruptly told to stop by the local councillor that was in charge - it was very much: "you've had your say, now it's time for us to make the decisions" (Community Interview 9)

This has precipitated, or in some cases confirmed, a scepticism of state-led participation. In theory, such views 'buy-in 'to the powerful anti-state spatial imaginary that draws on long-held 
Conservative beliefs in personal responsibility, voluntarism and civic associations (Featherstone et al., 2012), yet the zero-sum understanding of state-society relations and the belief that a restricted role for local government would galvanise local collective action appears to be misplaced since Neighbourhood Plans appear to fare best when co-produced between communities and local government planners (Parker et al., 2015).

\section{Spaces of community agency}

The assumption that communities could or would move into the space vacated a retrenched local state to deliver significant housing growth therefore appears to have been misplaced. Rather than deliver additional housing growth, the majority of participants in this study sought to finesse housing delivery through the location of sites, creating more detailed affordable housing policies and stitching development into the existing built environment through design policies. These represent significant successes for many communities and for the policy itself, albeit ones tempered by missed opportunities:

LPAs need to use Neighbourhood Plans to identify the sites that they can't - it could be a really bottom-up process but it's not been grasped ... a lot of plans are just replicating Local Plan policy, but also lots of innovation gets lost - local homes, [community land trusts], self-builds etc. - sometimes because of people like me, but also because there's a narrative about allocating sites (Consultant Interview 2).

Added value is also achieved through opportunities for local action beyond the "invited spaces" or participation (Cornwall, 2008). The invitation to "shape the future" (DCLG, 2013: 6) of the places where people live and work has been embraced by many communities, but not necessarily in ways in line with intended outcomes of Neighbourhood Planning:

... government don't realise what a powerful animal they've unleashed, it's bigger movement than they realise ... [the plan] will become a powerful ... maybe not in planning terms but in getting a primary school or whatever - Crossrail have noticed the same with people getting involved, it's about securing what local people want (Community Interview 27). 
The convening power of Neighbourhood Planning has encouraged communities to mobilise, whilst providing lines of communication with LAs and creating new democratic spaces. One means of co-opting these new spaces has been in the form of community engagement, linking consultation exercises to cultural events, for example exploring issues of representation and legitimacy in participatory planning through theatre (Cowie, 2017). Bradley (2017) has sought to show local narratives of place identity can provide the frame for the location, size and scale of housebuilding. In such examples, Neighbourhood Planning "can be seen as a re-appropriation of space from the dominant market model with the neighbourhood emerging as the proponent of sustainability and social purpose in housebuilding" (Bradley and Sparling, 2017: 116). A much publicised example can be seen in St Ives' principal-residence policy, which prevents newly built houses from being used as second homes. Further examples include communities adopting a zoning approach to preserve local architecture and heritage, producing design codes, and establishing community land trusts and co-operatives that provide alternatives to volume housebuilders. Such examples provide a counter-narrative to the government's construction of pro-growth localism through an ambivalence to financial inducements and prioritising social needs over governmental targets.

A common approach has been to include recommendations for community projects within Neighbourhood Plans, for example, by designating future CIL receipts for specific projects: as one participant put it: "the development is coming anyway, we might as well get something we want or need out of it" (Community Interview 5). Whilst falling outside the statutory scope of land-use planning policy, such recommendations are nonetheless underpinned by evidence, formalised as part of the adopted plan, and provide a bargaining chip for future negotiations with developers and the LA. By co-opting the invited participatory space to go beyond the formal remit of Neighbourhood Planning, some communities have been able to deliver wider community aims, still others have used the community engagement exercises to launch Community Governance 
Reviews $^{8}$ or establish People's Audits of their local council. Such examples can be seen as genuine expressions of community agency, governance by rather than through communities.

\section{Conclusion: Neoliberalism and 'Failing' Technologies}

Localism continues to be an attractive strategy for central governments seeking to achieve their aims within complex societies. Spatially-based technologies play an increasingly prominent role in delivering governmental outcomes within the UK's patchwork of local governance in ways that are still unfolding. This paper has sought to show how post-2010 localism has sought to define, mobilise and deploy local communities as agents of governance by seeking to give them "a share in local growth" (Conservative Party, 2009: 2). This has advocated less intervention but not less government, as communities become both the subject and object of neoliberal governmental agendas.

Central to this process has been making the spatial more visible in the social by promoting a neoliberal understanding of society as an aggregation of (competing) locales and "render the social domain economic" (Lemke, 2001: 213; Davoudi and Madanipour, 2013). The overtly pro-growth orientation of initiatives such as Neighbourhood Planning, predicated on a streamlined state and 'responsible' communities responding to their economic self-interest underscores how such processes seek to unify social and economic realms, as Lemke (2019: 258) states:

The importance of neoliberalism ... lies in its efforts to do away with tension between the social and economic realms. The former is no longer mobilized by (and against) the latter; instead; the two are joined together ... Integrating economic constraint into the social sphere combines greater efficiency with lower costs and promotes the 'autonomization of the social'.... Neoliberalism encourages individuals to give their lives entrepreneurial form. It reacts to increased 'demand' for self-fashioning and autonomy by extending an 'offer' to individuals and collectives: they should actively participate in solving matters and problems which, until this point, had been the responsibility of specialized and appointed state apparatuses. The 'price' is that they themselves must take on responsibility for such participation - and their own failure.

\footnotetext{
${ }^{8}$ A process that allows for the creation, grouping/de-grouping, or abolition of Town and Parish Councils. The process may be brought about the principal authority or by communities via a petition.
} 
By assigning a distinct scale to governmental technologies, the local has become the central site through which liberal concepts such as freedom and choice are deployed, creating a new social topography marked by the 'offer' of participation directed toward achieving governmental ends. Neighbourhood Planning has produced evidence of instrumentality and conservatism on behalf of communities fearful of how their plans will fare in a neoliberal development environment - yet it also creates opportunities to pursue wider aims relating to conservation, environmental protections and social forms of housing (Parker et al., 2015; 2017; Field and Layard, 2017; Bradley and Sparling, 2017). As such, Neighbourhood Planning can be seen as one part of an ongoing project of neoliberalisation that is able to subsume progressive concepts such sustainability and empowerment via "carefully choreographed" participation that gives the superficial appearance of engagement (Allmendinger and Haughton, 2012: 90) insofar as they do not conflict with the central goal of economic growth.

On a discursive level it is easy enough to reconcile this analysis with more optimistic accounts (e.g. Bradley; 2015, 2017; Bradley and Sparling, 2017), since progressive social and environmental improvements can be promoted within complex neoliberal landscapes by deploying 'fuzzy' concepts that command popular support (such as sustainability or empowerment) and appeal to broadly progressive if non-specific narratives that blur mechanisms of accountability (Allmendinger and Haughton, 2012; Haughton et al., 2013). In light of this, this paper has sought to show the continuing value of governmentality as a theoretical frame by demonstrating how political rationalities are always incomplete and necessarily translate into more or less effective technologies of rule that seek to capture certain populations, as Rose (2017:314) describes:

Political thought becomes governmental when it can link itself to a technology that seems to provide a means of realization - though ... one that usually is 'congenitally failing'; that is to say, it fails to live up to the ambitions of those who try to construct it.

As we have seen, Neighbourhood Planning has failed in its ambition to increase housing growth (Lichfields, 2018). Whilst community 'wins' such as protecting green space, shaping development to local needs, and improving design should not be overlooked, it is clear that Neighbourhood 
Planning has been caught between a series of irresolvable tensions that have beset localism and local planning for decades, not least the conflicting demands of local control versus strategic priorities. Its shortcomings therefore are not unique. Yet rendering government's competing and contradictory rationalities internally consistent is a never-ending process - by rooting the above analysis in the perceptions of local actors, this paper has sought to show how governmentalityinspired studies do not overlook the autonomy of local actors (cf. O’Hare, 2018: 210), but rather show that in practice government agendas are far from totalising. Instead they are continually contested and influenced by the actions of subjects who respond to government agendas in a variety of ways, thereby playing an active part in the reproduction of local structures through challenge and contest (Raco, 2003).

As such, the aim of this paper has not been to undermine the promise of localism (or Neighbourhood Planning more specifically) that has been argued for elsewhere (Williams et al., 2014; Wargent and Parker, 2018), but to recognise the art of government as a "congenitally failing operation" (Miller and Rose, 1990: 10; Rose et al., 2006). Governmental technologies necessarily play out within the context of wider struggles for social justice and democratic legitimacy, rendering their outcomes uncertain as they are more or less likely to 'win out' against competing local agendas (Newman, 2014). Put more dramatically: governmental technologies contain the "twin possibilities of domination and freedom" (Cruikshank, 1999: 2). Linking the inherent contradictions in the rationalities that underpin post-2010 localism to 'failing' - although not irrevocably failed - technologies does not conflate accounts that prioritise governance through or by communities but seeks to show how misplaced attempts at the former may open up opportunities for the latter. In short, understanding how political rationalities are more or less visibly "constantly undergoing modification in the face of some newly identified problem or solution" (Rose, et al., 2006: 98) is central explaining neoliberalism's ability to fail forwards (Peck, 2010). 


\section{References}

Allmendinger, P. and Haughton, G. (2012) 'Post-political spatial planning in England: a crisis of consensus?', Transactions of the Institute of British Geographers, 37(1): 89-103.

Barnes, M., Newman, J. and Sullivan, H. (2007) Power, Participation and Political Renewal: Case Studies in Public Participation, Bristol, Policy Press.

Blair, T. (1997) Leading the way - a new vision for local government, London, Institute for Public Policy Research.

Blair, T. (2002) 'New Labour and Community', Renewal, 20(2).

Bradley, Q. (2015) 'The political identities of neighbourhood planning in England', Space and Polity, 19(2): 97-109.

Bradley, Q. (2017) 'Neighbourhood planning and the impact of place identity on housing development in England', Planning Theory \& Practice, 18(2): 233-248.

Bradley, Q. and Sparling, W. (2017) 'The impact of neighbourhood planning and localism on house-building in England', Housing, Theory and Society, 34(1): 106-118.

Brownill, S. (2017) 'Assembling neighbourhoods: topologies of power and the reshaping of planning', in Brownill, S. and Bradley, Q. (eds.) Localism and neighbourhood planning: Power to the people?, Bristol, Policy Press, pp.145-162.

Brownill, S. and Bradley, Q. (eds.) (2017) Localism and neighbourhood planning: Power to the people?, Bristol, Policy Press.

Cameron, D. (2011) 'Speech on the Big Society', 23 May 2011. Available:

https://www.gov.uk/government/speeches/speech-on-the-big-society (accessed: 10 July 2019).

Clarke, N. and Cochrane, A. (2013) 'Geographies and politics of localism: the localism of the United Kingdom's coalition government', Political Geography, 34: 10-23.

Colomb, C. (2017) 'Participation and conflict in the formation of Neighbourhood Areas and Forums in 'super- diverse 'cities', in Brownill, S. and Bradley, Q. (eds.) Localism and Neighbourhood Planning: Power to the People?, Bristol, Policy Press, pp.127-144.

Conservative Party (2009) Control Shift: Returning power to local communities, Responsibility Agenda, London, Conservative Party.

Conservative Party (2010a) Open Source Planning, London, Conservative Party.

Conservative Party (2010b) Building a Big Society, London, Conservative Party.

Conservative Party (2010c) Invitation to Join the Government of Britain: The Conservative Manifesto 2010, London, Conservative Party.

Cornwall, A. (2008) 'Unpacking 'Participation': models, meanings and practices', Community Development Journal, 43(3): 269-283.

Corry, D. and Stoker, G. (2002) New Localism: Refashioning the Centre-Local Relationship, London, The New Local Government Network.

Cowie, P. (2017) 'Performing planning: understanding community participation in planning through theatre', Town Planning Review, 88(4): 401-421. 
Cruikshank, B. (1999) The Will to Empower, Ithica, Cornell University Press.

Davoudi, S. and Madanipour, A. (2013) 'Localism and neo-liberal governmentality', Town Planning Review, 84(5): 551-562.

Dean, M. (2010) Governmentality: Power and Rule in Modern Society, London, Sage.

DEFRA [Department for Environment, Food and Rural Affairs] (2013) Neighbourhood Planning, The rural frontrunners: research and case studies, London, DEFRA.

DCLG [Department for Communities and Local Government] (2008) Communities in control: Real people, real power, London, DCLG.

DCLG (2009) Transforming Places; Changing Lives A Framework for Regeneration, London, DCLG.

DCLG (2011) Regeneration to enable growth: What Government is doing in support of community-led regeneration, London, DCLG.

DCLG (2012a) Neighbourhood Planning, November 2012, London, DCLG.

DCLG (2012b) Localism Act: Neighbourhood Plans and Community Right to Build: Impact assessment, London, DCLG.

DCLG (2013) You've got the power. A quick and simple guide to community rights, London, DCLG.

DCLG (2016) Neighbourhood Planning: progress on housing delivery, October 2016, London, DCLG.

Evans, M., Marsh, D. and Stoker, G. (2013) 'Understanding localism', Policy Studies, 34(4): 401407.

Featherstone, D., Ince, A., Mackinnon, D., Strauss, K. and Cumbers, A. (2012) 'Progressive Localism and the Construction of Political Alternatives', Transactions of the Institute of British Geographers, 37(2): 177-182.

Field, M. and Layard, A. (2017) 'Locating community-led housing within neighbourhood plans as a response to England's housing needs', Public Money and Management, 37(2): 105-112.

Foucault, M. (1977) 'The Confession of the Flesh', in Gordon, C. (ed.) Power/Knowledge Selected Interviews and Other Writings, Brighton, Harvester Press, pp. 194-228.

Foucault, M. (1990) The History of Sexuality: Volume 1; An Introduction, London, Penguin.

Foucault, M. (1991) 'Governmentality' in Burchell, G., Gordon, C. and Miller, P. (eds.) The Foucault Effect: Studies in Governmentality, London, Harvester Wheatsheaf, pp.87-104.

Gallent, N. (2013) 'Re-connecting 'people and planning': parish plans and the English Localism agenda', Town Planning Review, 84(3): 371-396.

Gallent, N., Hamiduddin, I. and Madeddu, M. (2013) 'Localism, down-scaling and the strategic dilemmas confronting planning in England', Town Planning Review, 84(5): 563-582.

Glasman, M. (2010) 'Society not State: The challenge of the Big Society', Public Policy Research, 17(2): 59-63. 
Haughton, G., Allmendinger, P. and Oosterlynck, S. (2013) 'Spaces of Neoliberal Experimentation: soft spaces, post-politics, and neoliberal governmentality', Environment and Planning A, 45(1): 217-234.

Inch, A., Dunning, R., While, A., Hickman, H. and Payne, S. (2020) 'The object is to change the heart and soul': Financial incentives, planning and opposition to new housebuilding in England', Environment and Planning C: Politics and Space, published online 24 January 2020.

Hickson, K. (2013) 'The localist turn in British politics and its critics', Policy Studies, 34(4): 408421.

Lemke, T. (2001) ' The birth of bio-politics '- Michel Foucault's lecture at the Collège de France on neo-liberal governmentality', Economy and Society, 30(2): 190-207.

Lemke, T. (2019) Foucault's Analysis of Modern Governmentality, London, Verso.

Li, T. (2007) The Will to Improve: Governmentality, Development, and the Practice of Politics, London, Duke University Press.

Lichfields (2018) Local choices? Housing delivery through Neighbourhood Plans, May 2018. https://lichfields.uk/media/4128/local-choices_housing-delivery-through-neighbourhood-plans.pdf (accessed 12 August 2019).

Lowndes, V. and Pratchett, L. (2012) 'Local Governance under the Coalition Government: Austerity, Localism and the 'Big Society', Local Government Studies, 38(1): 21-40.

Lowndes, V. and Sullivan, H. (2008) 'How low can you go? Rationales and challenges for neighbourhood governance', Public Administration, 86(1): 53-74.

Lupton, R. (2013) 'What is neighbourhood renewal policy for?', People, Place and Policy, 7(2): 66-72.

McGuinness, D. and Mawson, J. (2017) 'The rescaling of sub-national planning: can localism resolve England's spatial planning conundrum?', Town Planning Review, 88(3): 283-303.

Miller, P. and Rose, N. (1990) 'Governing economic life', Economy and Society, 19(1): 1-31.

Miller, P. and Rose, N. (2008) Governing the present: Administrating economic, social and personal life, Cambridge, Polity Press.

Mouffe, C. (2005) On the Political, London, Verso.

Newman, J. (2001) Modernising Governance, London, Sage.

Newman, J., Barnes, M., Sullivan, H. and Knops, A. (2004) 'Public Participation and Collaborative Governance', Journal of Social Policy, 33(2): 203-233.

Newman, J. (2014) 'Landscapes of antagonism: local governance, neo-liberalism and austerity', Urban Studies, 51(15): 3290-3305.

Norman, J. (2010) The Big Society: The Anatomy Of The New Politics, Buckingham, The University of Buckingham Press.

O'Hare, P. (2018) 'Resisting the 'Long-Arm' of the State? Spheres of Capture and Opportunities for Autonomy in Community Governance', International Journal of Urban and Regional Research, 42(2): 210-225. 
Parker, G., Lynn, T. and Wargent, M. (2014) User Experience of Neighbourhood Planning in England, London, Locality.

Parker, G., Lynn, T. and Wargent, M. (2015) 'Sticking to the Script? The Co-production of Neighbourhood Planning in England', Town Planning Review, 86(5): 519-536.

Parker, G., Lynn, T. and Wargent, M. (2017) 'Contestation and Conservatism in Neighbourhood Planning in England. Reconciling Agonism and Collaboration?', Planning Theory \& Practice, 17(3): 446-465.

Parker, G. and Salter, K. (2016) 'Five years of neighbourhood planning - a review of take-up and distribution', Town and Country Planning, 85(5): 181-188.

Peck, J. (2010) Constructions of Neoliberal Reason, Oxford, Oxford University Press.

Pemberton, S. (2017) 'Community-based planning and localism in the devolved UK', in Brownill, S. and Bradley, Q. (eds.) Localism and Neighbourhood Planning: Power to the People?, Bristol, Policy Press, pp.183-198.

Raco, M. (2003) 'Governmentality, subject-building, and the discourses and practices of devolution in the UK', Transactions of the Institute of British Geographers, 28(1): 75-95.

Raco, M. and Imrie, R. (2000) 'Governmentality and rights and responsibilities in urban policy', Environment and Planning A, 32(12): 2187-2204.

Rohe, W.M. (2009) 'From local to global: one hundred years of neighborhood planning', Journal of the American Planning Association, 75(2): 209-230.

Rose, N. (1996) 'Governing 'advanced 'liberal democracies', in Barry, A., Osbourne, T. and Rose, N. (eds.) Foucault and Political Reason, London, UCL Press, pp.37-64.

Rose, N. (2017) 'Still 'like birds on the wire'? Freedom after neoliberalism', Economy and Society, 46(3-4): 303-323.

Rose, N., O’Malley, P. and Valverde, M. (2006) 'Governmentality', Annual Review of Law and Social Science, 2: 83-104.

SEU [Social Exclusion Unit] (1998) Bringing Britain Together: A National Strategy for Neighbourhood Renewal, London, The Stationery Office.

SEU (2001) A New Commitment to Neighbourhood Renewal: National Strategy Action Plan, London, The Stationery Office.

Stanier, R. (2014) 'Neighbourhood Planning', $42^{\text {nd }}$ Joint Planning Law Conference, New College Oxford, 19-21 September, 2014.

Stoker, G. (2004) 'New Localism, Progressive Politics and Democracy', The Political Quarterly, 75(1): 117-129.

Stoker, G. (2011) 'Was local governance such a good idea? A global comparative perspective', Public Administration, 89(1): 15-31.

Sturzaker, J. (2011) 'Can Community Empowerment Reduce Opposition to Housing? Evidence from Rural England', Planning, Practice and Research, 26(5): 555-570.

Swyngedouw, E. (2005) 'Governance innovation and the citizen: the janus face of governancebeyond-the-state', Urban Studies, 42(11): 1991-2006. 
Tait, M. and Inch, A. (2016) 'Putting Localism in Place: Conservative Images of the Good Community and the Contradictions of Planning Reform in England', Planning Practice \& Research, 31(2): 174-194.

Taylor, M. (2007) 'Community Participation in the Real World: Opportunities and Pitfalls in New Governance Spaces’, Urban Studies, 44(2): 297-317.

Wargent, M. and Parker, G. (2018) 'Re-imagining neighbourhood governance: the future of neighbourhood planning in England', Town Planning Review, 89(4): 379-402.

Wargent, M., Parker, G. and Street, E. (2020a) 'Public-private entanglements: consultant use in the English planning system', European Planning Studies, 28(1): 192-210.

Wargent, M., Parker, G. and Street, E. (2020b) 'Private expertise and the spatial reorganisation of planning in England', in Jonas, A.E.G., Koch, N., Lizotte, C., Luukkonen, J. and Moisio, S. (eds.) Handbook on the Changing Geographies of the State, Cheltenham, Edward Elgar, in press.

Watson, V. (2014) 'Co-production and collaboration in planning - The difference', Planning Theory \& Practice, 15(1): 62-76.

Williams, A., Goodwin, M. and Cloke, P. (2014) 'Neo-liberalism, Big Society and progressive localism', Environment and Planning A, 46(12): 2798-2815. 